\title{
Faktor Penentu Kinerja Manajerial: Studi pada Perguruan Tinggi Negeri di Jakarta
}

\author{
Efrida Yasni Nasution ${ }^{1}$, Hermiyetti ${ }^{2}$ \\ ${ }^{1}$ Universitas Pancasila Jakarta, ${ }^{2}$ Universitas Bakrie \\ yasni.efrida@gmail.com, hermiyetti99@gmail.com
}

\begin{abstract}
This study aims to analyse the influence of budget participation and role conflict on managerial performance, how professional orientation can moderate the relationship of budget participation and role conflict on managerial performance. This study has selected 66 lecturers from three universities (UI, UNJ dan UIN Jakarta). The data collected were analyzed using Moderated Regression Analysis (MRA). The research has resulted in the following conclusions: The budget participation does not affect the performance of managerial, The professional orientation functions as moderating variables (pure moderator) to strengthen the relationship between budgetary participation on managerial performance, The role conflict is influential on managerial performance and the professional orientation functions as moderating variables (quasi-moderator) so as to strengthen the relationship between role conflict and managerial performance.
\end{abstract}

Keywords: managerial performance, budget participation, role conflict, moderated regression analysis.

\begin{abstract}
Abstrak
Penelitian ini bertujuan untuk mengetahui secara empiris pengaruh partisipasi dan konflik peran terhadap kinerja manajerial dan orientasi profesional dapat memoderasi hubungan partisipasi anggaran dan konflik peran terhadap kinerja manajerial. Sampel penelitian ini sebanyak 66 dosen dari tiga Universitas (UI, UNJ dan UIN Jakarta). Data dianalisis menggunakan teknik Moderated Regression Analysis (MRA). Hasil penelitian menunjukan bahwa partisipasi anggaran tidak berpengaruh terhadap kinerja manajerial, orientasi professional merupakan variabel moderasi, sehingga dapat memperkuat hubungan antara partisipasi anggaran terhadap kinerja manajerial, konflik peran berpengaruh terhadap kinerja manajerial dan orientasi professional merupakan variabel moderasi, sehingga dapat memperkuat hubungan antara konflik peran terhadap kinerja manajerial
\end{abstract}

Kata Kunci: kinerja manajerial, partisipasi anggaran, konflik peran, moderated regression analysis

Diterima: 17 Februari 2017; Direvisi: 25 April 2017; Disetujui: 10 Mei 2017 


\section{PENDAHULUAN}

Peran para tenaga pengajar di Perguruan Tinggi mempunyai posisi yang cukup strategis, mereka selain sebagai dosen juga berperan sebagai manager pengelola institusi tersebut sehingga ada peran ganda dalam melakukan pekerjaan dalam lingkungan yang sama. Adanya peran ganda ini menyebabkan terjadi konflik peran yang mempengaruhi kinerja manajerial dalam pencapaian tujuan organisasi (Tjokorda, 2013). Kinerja manajerial adalah kemampuan manajer saat menjalankan fungsi manajemen. Penilaian kinerja merupakan salah satu faktor kunci untuk mengembangkan organisasi agar lebih efektif dan efisien. Anggaran dapat digunakan sebagai alat untuk menilai kinerja suatu organisasi dengan melakukan pengendalian dalam hal pengarahan dan pengendalian individu yang terlibat dalam organisasi.

Partisipasi dalam penyusunan anggaran terjadi apabila adanya keterlibatan dan tingkat pengaruh yang dirasakan oleh individu Partisipasi dosen atau pakar kampus kenyataannya sangat rendah dalam proses penganggaran salah satunya pada Universitas di Yogyakarta. Menurut Sukirno, dampak dari anggaran yang top down, tanpa partisipasi dari para dosen, anggaran universitas atau perguruan tinggi cenderung tidak berkualitas dan sarat kepentingan. Lemahnya partisipasi dosen dalam pengambilan keputusan penganggaran memperlemah komitmen, kepuasan dan kinerja dosen. Selain itu, produk anggaran semacam itu memerlemah kontrol dan kualitas penganggaran perguruan tinggi (Pikiran Rakyat Online, 12 November 2014).

Dalam penyusunan anggaran yang menjadi salah satu hal yang perlu diperhatian adalah penganggaran partisipasif (partisipasi dalam menyusun anggaran) dari pegawai yang bertanggung jawab atas pelaksanaan anggaran, baik dalam penyusunan anggaran awal maupun revisi, dengan tujuan untuk mencapai suatu kesepakatan bersama atas anggaran wajar dan dapat dicapai. Hope dan Fraser (2003) dalam Andison dan Augustine (2017), mengemukakan bahwa anggaran memiliki fungsi sebagai alat penilaian kinerja. Kinerja akan dinilai berdasarkan pencapaian target anggaran dan efisiensi pelaksanaan anggaran. 
Kinerja manajer dinilai berdasarkan berapa yang berhasil dicapai dikaitkan dengan anggaran yang telah ditetapkan.

Penganggaran merupakan mekanisme pengendalian administrasi formal yang didesain menurut prinsip pengendalian birokrasi (Abernethy dan Stoelwinder, 1995). Pengendalian ini diperlukan untuk mengendalikan perilaku staf auditor yang mendominasi keputusan dalam memberikan pelayanan yang biasanya kurang mempertimbangkan konsekuensi finansial. Para profesional cenderung memiliki komitmen yang tinggi terhadap nilai-nilai profesional tetapi memiliki komitmen yang rendah terhadap nilai manajerial sehingga melibatkan mereka dalam pengendalian akuntansi seperti dalam penganggaran, kemungkinan akan menimbulkan konflik peran (Comerford dan Abernethy, 1999; dalam Lidya dan Susilawati, 2009).

Konflik terjadi karena tenaga kerja profesional memiliki norma dan sistem nilai yang diperolehnya dalam proses pendidikan berbenturan dengan norma, aturan dan sistem nilai yang berlaku di perusahaan. Berbagai studi sebelumnya menunjukkan bahwa peran ganda ini berpotensi untuk menimbulkan dampak yang merugikan bagi organisasi dengan timbulnya konflik peran (Abernethy dan Stoelwinder, 1995; Comerford dan Abernethy, 1999). Beberapa bukti empiris menunjukkan bahwa tenaga kerja profesional yang bekerja dalam lingkungan organisasi yang birokratis mengalami konflik peran (role conflict) (Raelin, 1989; Copur, 1990; Comerford dan Abernethy, 1999). Rebele \& Michaels (1990) menyatakan bahwa konflik peran (role conflict) digambarkan sebagai derajat tingkat dari ketidakcocokan harapan-harapan yang dikomunikasikan oleh suatu pengirim peran kepada suatu penjabat peran (Lidya dan Susilawati, 2009).

Suharmanto (2010) menjelaskan bahwa para profesional akan mengalami konflik peran ketika mereka diharapkan untuk berpartisipasi dalam bentuk pengendalian birokratis. Misalnya pengendalian profesional yang menekankan pada self-control dipandang tidak sejalan dengan pengendalian birokratik. Jalan untuk menghindari apa yang disebut sebagai konflik profesional adalah dengan menghindari untuk mempertemukan para profesional dengan sistem birokrasi, yang membatasi aktivitas pengaturan diri mereka (Abernethy dan Stoelwinder, 
1995). Dengan demikian perguruan tinggi mengalami keadaan dimana para profesional akan menghadapi adanya tekanan yang meningkat untuk terlibat dalam penganggaran dan bentuk-bentukpengendalian administratif lainnya.

Keterlibatan para profesional dalam birokrat suatu organisasi, membawa implikasi dalam proses manajemen penganggaran. Sementara itu norma dan nilai yang dianut profesional tidak selalu sejalan dengan norma dan nilai yang diterapkan dalam birokrasi organisasi. Demikian juga model pengendalian profesional tidak selalu sejalan dengan model pengendalian birokratik. Potensi clash of culture dalam organisasi profesional-birokratik ini, biasanya tampil apabila dilihat dari perspektif sistem pengendalian manajemen, dimana profesional sangat memerlukan kemandirian, kebebasan dan kesamaan individu, sehingga keadaan ini membawa potensi terjadinya konflik peran bagi para profesional apabila profesional tersebut menjadi bagian dari birokatis, konflik ini disebut konflik profesional-birokrat (Suharmanto 2010).

Sebagai seorang dosen yang memiliki peran ganda yaitu sebagai akademisi/pendidik dan juga sebagai manajer pada jabatan struktural di Perguruan Tinggi. Sebagai seorang manajer ia harus mendasarkan pekerjaannya pada efisiensi dan pencapaian tujuan organisasi. Keberhasilan sebagai manajer akan diukur antara lain dengan pengendalian administratif atau birokratis yang salah satunya dilakukan melalui proses penganggaran. Adapun pengendalian melalui mekanisme anggaran sering juga disebut dengan pengendalian akuntansi. Sedangkan sebagai seorang akademisi, ia harus berorientasi pada nilai-nilai profesinya yang secara spesifik disebut dengan orientasi profesional.

Berdasarkan uraian diatas konflik profesional-birokrat adalah konflik peran yang disebabkan adanya peran ganda yang dimiliki seseorang yaitu sebagai anggota profesi yang menjalankan fungsi dan sebagai jajaran birokrat atau manajer di tempat mereka bekerja. Dalam penelitian ini para profesional yang dimaksud adalah para profesional dalam bidang pendidikan, yaitu dosen. Konflik peran ini akan dilihat dari sudut pandang seberapa besar keterlibatan mereka dalam proses penganggaran yang merupakan bagian penting dalam pengendalian manajemen yang merupakan salah satu tolak ukur penilaian kinerja (Supomo, Indriantoro, 
1998). Kinerja manajerial merupakan salah satu faktor yang dapat meningkatkan keefektifan organisasional.

Penelitian ini bertujuan untuk: Pertama, menganalisis apakah partisipasi anggaran berpengaruh terhadap kinerja manajerial. Kedua, untuk menganalisis apakah konflik peran berpengaruh terhadap kinerja manajerial. Ketiga, untuk menganalisis apakah orientasi professional mempengaruhi hubungan partisipasi anggaran terhadap kinerja manajerial. Keempat, untuk menganalisis apakah orientasi professional mempengaruhi hubungan konflik peran terhadap kinerja manajerial.

Melalui penelitian ini diharapkan dapat memberikan kontribusi terhadap pengetahuan yang berkaitan dengan masalah ini, dan sekaligus sebagai bahan kajian serta masukan bagi peneliti selanjutnya dalam mengembangkan keilmuan yang berkaitan dengan konsep, teori tentang pengaruh partisipasi penyusunan anggaran dan konflik peran terhadap kinerja manajerial serta orientasi profesional sebagai variable pemoderasi.

\section{METODE}

Pengumpulan data penelitian ini dengan pemilihan sampel secara purposive sampling berdasarkan judgement, yaitu dosen yang dijadikan responden adalah mereka yang juga menduduki jabatan struktural di perguruan tinggi masingmasing. Pemilihan tersbut dilakukan dengan harapan mampu memberikan jawaban yang tepat sesuai dengan fokus penelitian. Objek penelitian terdiri dari tiga Perguruan Tinggi Negeri di Jakarta yaitu Universitas Indonesia, Universitas Negeri Jakarta dan Universitas Islam Negeri Jakarta.

Adapun metode analisis yang digunakan adalah Moderated Regression Analysis (MRA). MRA merupakan aplikasi khusus regresi linear berganda di mana mengandung unsur interaksi persamaan regresi (perkalian dua atau lebih variabel independen)

Berdasarkan hubungan antar variabel partisipasi anggaran (PA), konflik peran (KP), orientasi profesional (OP) dan kinerja manajerial (KM). maka persamaan regresi yang digunakan adalah: 


\section{$\mathrm{KM}=\alpha+\beta_{1} \mathrm{PA}+\beta_{2} \mathrm{KP}+\beta_{3} \mathrm{OP}+\beta_{4} \mathrm{PA} * \mathrm{OP}+\beta_{5} \mathrm{KP} * \mathrm{OP}+e$}

Keterangan:

$$
\begin{aligned}
& \mathrm{KM}=\text { Kinerja Manajerial } \\
& \mathrm{PA}=\text { Partisipasi Anggaran } \\
& \mathrm{KP}=\text { Konflik Peran } \\
& \mathrm{OP}=\text { Orientasi Profesional }
\end{aligned}
$$

\section{HASIL DAN PEMBAHASAN}

Tabel 1 menunjukkan nilai $\mathrm{R}$ sebesar 0.433 atau 43.3\%. Hal ini berarti bahwa hubungan atau korelasi antara kinerja manajerial dengan partisipasi anggaran, konflik peran dan orientasi profesional adalah sebesar 43.3\%. Nilai Adjusted R Square sebesar 0.386 atau 38.6\%, ini menunjukkan bahwa variabel kinerja manajerial yang dapat dijelaskan oleh variabel partisipasi anggaran, konflik peran, orientasi profesional, interaksi partisipasi anggaran dengan orientasi profesional, dan interaksi konflik peran dengan orientasi profesional adalah sebesar 38.6\%, sedangkan sisanya sebesar 0.614 atau $61.4 \%$ dijelaskan oleh faktor-faktor lain yang tidak disertakan dalam model penelitian ini.

Tabel 1. Hasil Uji Koofisien Determinasi

\begin{tabular}{lllll}
\hline Model & $\mathrm{R}$ & R Square & Adjusted R Square & $\begin{array}{c}\text { Std. Error of the } \\
\text { Estimate }\end{array}$ \\
\hline 1 & $.658^{\mathrm{a}}$ & .433 & .386 & .56587 \\
\hline a. Predictors: (Constant) $\mathrm{PA}$, & $\mathrm{OP}, \mathrm{KP}^{2} \mathrm{PA}^{*} \mathrm{OP}, \mathrm{KP}^{*} \mathrm{OP}$ &
\end{tabular}

a. Predictors: (Constant), PA, OP, KP, $\mathrm{PA}^{*} \mathrm{OP}, \mathrm{KP}^{*} \mathrm{OP}$,

Sumber: data diolah 2015

Tabel 2 menyajikan hasil uji statistik t untuk variabel partisipasi anggaran, konflik peran, orientasi profesional, interaksi partisipasi anggaran dengan orientasi profesional, dan interaksi konflik peran dengan orientasi profesional dalam menerangkan kinerja manajerial. 
Tabel 2. Hasil Uji Statistik

\begin{tabular}{|c|c|c|c|c|c|c|}
\hline \multirow[b]{2}{*}{ Model } & & \multicolumn{2}{|c|}{$\begin{array}{l}\text { Unstandardized } \\
\text { Coefficients }\end{array}$} & \multicolumn{3}{|c|}{$\begin{array}{l}\text { Standardized } \\
\text { Coefficients }\end{array}$} \\
\hline & & B & Std. Error & Beta & $\mathrm{t}$ & Sig. \\
\hline \multirow[t]{6}{*}{1} & (Constant) & 5.967 & 2.648 & & 2.253 & .028 \\
\hline & PA & -1.180 & .606 & -1.008 & -1.946 & .056 \\
\hline & KP & 1.805 & .761 & 1.241 & 2.371 & .021 \\
\hline & $\mathrm{OP}$ & .412 & .832 & .308 & .495 & .622 \\
\hline & $\mathrm{PA}^{*} \mathrm{OP}$ & .360 & .179 & 1.725 & 2.009 & .049 \\
\hline & $\mathrm{KP} * \mathrm{OP}$ & -.625 & .227 & -1.470 & -2.756 & .008 \\
\hline
\end{tabular}

a. Dependent Variable: KM

Sumber: data diolah 2015

Berdasarkan tabel diatas, persamaan model regresi linear berganda dalam penelitian ini dapat dinyatakan sebagai berikut:

$\mathrm{KM}=5,967-0,180 \mathrm{PA}+1,805 \mathrm{KP}+0,412 \mathrm{OP}+0,360 \mathrm{PA}^{*} \mathrm{OP}-0,625 \mathrm{KP} * \mathrm{OP}+\varepsilon$

Penjelasan mengenai pengaruh variabel-variabel independen terhadap variabel dependen secara parsial dapat diuraikan sebagai berikut:

\section{Partisipasi Anggaran terhadap Kinerja Manajerial}

Dari hasil uji t diketahui bahwa nilai t-hitung partisipasi anggaran terhadap kinerja manajerial sebesar -1.946 dengan tingkat signifikansi $0.056(\geq 0.05)$. Maka dapat disimpulkan bahwa hipotesis 1 (H1) ditolak, yang berarti partisipasi anggaran tidak berpengaruh terhadap kinerja manajerial karena tingkat signifikansi yang dimiliki variabel partisipasi anggaran lebih besar dari 0.05. Nilai koefisien korelasi partisipasi anggaran adalah sebesar -1.180. Hal tersebut berarti apabila nilai koefisien regresi variabel independen lainnya tetap (tidak berubah), maka peningkatan 1 (satu) satuan partisipasi anggaran akan meningkatkan kinerja manajerial sebesar 0.001 satuan.

\section{Partisipasi Anggaran terhadap Kinerja Manajerial dengan Orientasi} Profesional sebagai Variabel Pemoderasi.

Dari hasil uji t diketahui bahwa nilai t-hitung partisipasi anggaran terhadap kinerja manajerial dengan orientasi profesional sebagai variabel moderasi sebesar 2.009 dengan tingkat signifikansi $0.049(\leq 0,05)$. Maka disimpulkan hipotesis 2 (H2) diterima, yang berarti terdapat pengaruh positif partisipasi anggaran 
terhadap kinerja manajerial dengan orientasi profesional sebagai variabel pemoderasi. Adapun partisipasi anggaran terhadap kinerja manajerial dengan orientasi profesional sebagai variabel pemoderasi termasuk ke dalam jenis variabel moderator kuadran 4 yaitu pure moderator (moderator asli), dimana partisipasi anggaran berhubungan dengan kinerja manajerial dan orientasi profesional sebagai variabel moderasi ketika berinteraksi dengan partisispasi anggaran berpengaruh signifikan terhadap kinerja manajerial. lebih jelasnya dapat dilihat pada Tabel 3.

Tabel 3. Partisipasi Anggaran terhadap Kinerja Manajerial dengan Orientasi Profesional sebagai Variabel Pemoderasi

\begin{tabular}{lll}
\hline Berhubungan & dengan & Tidak berhubungan dengan \\
KM dan atau PA & & kriterior dan prediktor \\
\hline
\end{tabular}

Tidak berinteraksi

dengan PA

Berinteraksi $\quad \mathbf{P A} \rightarrow \mathbf{K M}=\mathbf{0 , 5 6}$

dengan PA $\quad \mathbf{P A}^{*} \mathbf{O P}=\mathbf{0 , 0 4 9}$

Sumber: data diolah 2015

Nilai koefisien korelasi interaksi partisipasi anggaran dengan orientasi profesional adalah sebesar 0,360. Hal tersebut berarti apabila nilai koefisien regresi variabel independen lainnya tetap (tidak berubah), maka peningkatan 1 (satu) satuan interaksi partisipasi anggaran dengan orientasi profesional akan meningkatkan kinerja manajerial sebesar 0.001 satuan.

\section{Konflik Peran terhadap Kinerja Manajerial}

Dari hasil uji t diketahui bahwa nilai t-hitung konflik peran terhadap kinerja manajerial sebesar 2.371 dengan tingkat signifikansi $0.021(\leq 0.05)$. Maka dapat disimpulkan bahwa hipotesis 3 (H3) diterima, yang berarti konflik peran berpengaruh terhadap kinerja manajerial karena tingkat signifikansi yang dimiliki variabel partisipasi anggaran lebih kecil dari 0,05. Nilai koefisien korelasi konflik peran adalah sebesar 1,805. Hal tersebut berarti apabila nilai koefisien regresi variabel independen lainnya tetap (tidak berubah), maka peningkatan 1 (satu) satuan konflik peran akan meningkatkan kinerja manajerial sebesar 0,001 satuan.

\section{Konflik Peran terhadap Kinerja Manajerial dengan Orientasi Profesional sebagai Variabel Pemoderasi.}


Dari hasil uji t diketahui bahwa nilai t-hitung konflik peran terhadap kinerja manajerial dengan orientasi profesional sebagai variabel moderasi sebesar -2.576 dengan tingkat signifikansi $0.008(\leq 0.05)$. Maka dapat disimpulkan bahwa hipotesis 4 (H4) diterima, yang berarti terdapat pengaruh positif partisipasi anggaran terhadap kinerja manajerial dengan orientasi profesional sebagai variabel pemoderasi. Adapun partisipasi anggaran terhadap kinerja manajerial dengan orientasi profesional sebagai variabel pemoderasi termasuk ke dalam jenis variabel moderator kuadran 3 yaitu quasi moderator (moderator semu), dimana partisipasi anggaran berhubungan dengan kinerja manajerial dan orientasi profesional sebagai variabel moderasi ketika berinteraksi dengan konflik peran berpengaruh signifikan terhadap kinerja manajerial. Untuk lebih jelasnya dapat dilihat pada Tabel 4.

Nilai koefisien korelasi interaksi konflik peran dengan orientasi profesional adalah sebesar $-0,625$. Hal tersebut berarti apabila nilai koefisien regresi variabel independen lainnya tetap (tidak berubah), maka peningkatan 1 (satu) satuan interaksi partisipasi anggaran dengan orientasi profesional akan meningkatkan kinerja manajerial sebesar 0,001 satuan.

Tabel 4. Konflik Peran terhadap Kinerja Manajerial dengan Orientasi Profesional sebagai Variabel Pemoderasi

\begin{tabular}{|c|c|c|}
\hline & $\begin{array}{ll}\text { Berhubungan } & \text { dengan } \\
\text { KM dan atau KP } & \\
\end{array}$ & $\begin{array}{l}\text { Tidak berhubungan dengan } \\
\text { kriterior dan prediktor }\end{array}$ \\
\hline $\begin{array}{ll}\text { Tidak } & \text { berinteraksi } \\
\text { dengan KP } & \end{array}$ & 3 & \\
\hline $\begin{array}{l}\text { Berinteraksi } \\
\text { dengan KP }\end{array}$ & $\begin{array}{l}\mathrm{KP} \rightarrow \mathrm{KM}=0,021 \\
\mathrm{KP}^{*} \mathrm{OP}=0,008\end{array}$ & \\
\hline
\end{tabular}

Sumber: data diolah 2015

\section{Pembahasan}

Dari hasil analisis data dan pengujian hipotesis diatas diketahui bahwa partisipasi anggaran tidak berpengaruh terhadap kinerja manajerial, sehingga dapat disimpulkan hasil penelitian ini menolak hipotesis satu yang menyatakan partisipasi anggaran berpengaruh terhadap kinerja manajerial. Hal ini dikarenakan penganggaran merupakan suatu proses yang berbeda pada organisasi sektor publik dibandingkan dengan penganggaran pada sektor swasta. 
Penganggaran dalam organisasi sektor publik seperti halnya Perguruan Tinggi Negeri di Jakarta, anggaran Perguruan Tinggi Negeri yang sebagian besar berasal dari Penerimaan Negara Bukan Pajak (PNBP) biasanya sudah dialokasikan pemerintah sehingga para penerima anggaran dalam hal ini pihak Perguruan Tinggi menyusun program untuk merealisasikan anggaran yang telah disediakan, dalam hal ini partisipasi para manager menjadi tidak efektif dikarenakan terpaku pada alokasi anggaran yang telah disediakan walaupun terkadang tidak sepenuhnya sesuai dengan kebutuhan atau perencanaan yang telah dibuat. Hal ini jelas berbeda dengan sektor swasta dimana anggaran disusun dengan melibatkan mulai dari manajemen tingkat bawah sampai dengan manajemen tingkat atas sehingga partisipasi dalam pengganggaran lebih maksimal.

Penganggaran dalam sektor publik yang dilakukan dengan sistem top-down kurang maksimal dalam meningkatkan kinerja, maka dalam perkembangan sekarang ini Perguruan Tinggi Negeri di Jakarta mulai menggunakan model perencanaan yang lebih partisipatif, dimana dengan sistem anggaran seperti ini memungkinkan serapan aspirasi dari seluruh komponen sivitas akademika terutama pada setiap unit kerja dapat berpartisipasi dalam penyusunan anggaran hanya saja belum dilakukan secara maksimal. Dampak terhadap kinerjanya belum terjawab.

Dari hasil analisis data dan pengujian hipotesis diatas diketahui bahwa variabel orientasi profesional merupakan variabel moderating karena interaksi partisipasi anggaran terhadap kinerja manajerial dengan orientasi profesional sebagai variabel pemoderasi, termasuk ke dalam jenis variabel moderasi kuadran 4 yaitu pure moderator (moderator asli) dimana interaksi orientasi profesional partisipasi anggaran berpengaruh terhadap kinerja manajerial. Dengan demikian, orientasi profesional memperkuat hubungan antara partisipasi anggaran terhadap kinerja manajerial. Sehingga hasil penelitian ini menerima hipotesis dua.

Penelitian ini melibatkan dosen yang menjabat struktural di tingkat fakultas, ketika dosen menerima perannya sebagai manajer, saat itu pula adanya kesediaan untuk komit dengan segala konsekuensi yang ditimbulkan dari tuntutan peran yang diterima seperti mencurahkan waktu, tenaga dan konsentrasi. Hal ini 
menunjukkan bahwa komitmen yang kuat terhadap nilai manajerial tidak berarti mereka harus mengorbankan nilai-nilai profesional. Sehingga dengan sikap yang berorientasi pada professional dapat meningkatkan kinerja manajerial, sesuai dengan hasil penelitian ini terjawab bahwa kinerja manajerial meningkat dengan adanya partisipasi anggaran yang disertai dengan sikap profesional.

Seseorang dapat dikatakan profesional apabila melakukan profesinya dengan benar dan sesuai dengan etika profesi yang berlaku. Seorang dosen yang menjabat sebagai pejabat struktural di tingkat fakultas/unit kerja akan bertindak sebagai manajer. Sebagai manajer ia tidak terlepas dari bentuk-bentuk pengendalian yang diterapkan dalam organisasi. Salah satu bentuk pengendalian tersebut adalah anggaran. Anggaran merupakan salah satu bentuk dari pengendalian output untuk mengatur perilaku. Dengan adanya pengendalian tersebut, manajer tidak dapat lagi menentukan tindakan yang mereka inginkan secara pribadi. Karena para dosen yang juga sebagai manager terikat dengan peraturan dan prosedur organisasi. Adanya anggaran tersebut berarti perilaku para dosen yang juga manajer akan dibatasi dengan standar-standar atau ketentuan yang terdapat pada anggaran. Hal ini mengakibatkan berkurangnya otonomi terhadap pelaksanaan pekerjaan yang dirasakan oleh profesional tersebut. Hipotesis dua ini mendukung penelitian Yuniar (2010) dengan adanya anggaran sebagai alat evaluasi kinerja, para profesional dengan terpaksa harus melaksanakan ketentuan-ketentuan yang terdapat pada anggaran tersebut sehingga otonomi mereka untuk mengatur diri sendiri menjadi terbatas. Dengan demikian diharapkan adanya partisipasi anggaran dapat meningkatkan kinerja manajerial dengan didukung sikap yang berorientasi pada profesionalisme.

Hasil hipotesis dua ini mendukung penelitian Amilin \& Apriani (2013), responden pada penelitian ini adalah 54 orang para akuntan publik yang bekerja di KAP yang ada di DKI Jakarta. Hasil dari penelitian ini menunjukan bahwa orientasi professional berpengaruh nyata terhadap kinerja auditor. Semakin tinggi orientasi professional, semakin tinggi kinerja yang dihasilkan oleh auditor. Hal ini menunjukan bahwa apabila makin tinggi sikap keprofesionalan seseorang terkait dengan kode etik profesinya, maka kinerja yang dihasilkan pun makin baik. 
Dari hasil analisis data dan pengujian hipotesis diatas diketahui bahwa konfik peran berpengaruh terhadap kinerja manajerial, sehingga dapat disimpulkan hasil penelitian ini menerima hipotesis tiga yang menyatakan konflik peran berpengaruh terhadap kinerja manajerial. Konflik peran dapat terjadi dikarenakan adanya dua fungsi yang berbeda dimana kedua fungsi tersebut yaitu sebagai dosen dan manajer mempunyai dua tujuan yang berbeda. Sehingga ada salah satu peran baik sebagai dosen maupun sebagai manajer yang tujuannya tidak tercapai dengan maksimal dikarenakan salah satu peran yang tidak berjalan dengan sebagaimana mestinya. Konflik peran terjadi dikarenakan ada dua tekanan atau lebih yang terjadi secara bersamaan yang ditujukan kepada seseorang yang menjalankan dua fungsi yaitu sebagai dosen dan manager, dimana sebagai dosen harus bertanggung jawab terhadap kewajiban mengajar dan sebagai manager bertanggung jawab mengelola fakultas mulai dari kegiatan perencanaan sampai dengan pengawasan terhadap fakultas yang dipimpinnya. Dalam penelitian ini terjawab bahwa konflik peran dapat berpengaruh secara positif terhadap kinerja .

Konflik profesional-birokrat adalah konflik peran yang disebabkan adanya peran ganda yang dimiliki seseorang yaitu sebagai dosen yang menjalankan fungsi dan sebagai jajaran birokrat atau manajer di tempat mereka bekerja. Konflik peran ini akan dilihat dari sudut pandang seberapa besar keterlibatan mereka dalam proses penganggaran yang merupakan bagian penting dalam pengendalian manajemen. Konflik peran tersebut timbul sebagai akibat adanya pertentangan dalam diri individu yang bersangkutan atas penerapan sumber daya yang dilakukan melalui proses penganggaran. Karena individu tersebut rendah orientasi manajerialnya, dia bisa menyusun anggaran semata mata untuk memenuhi kepentingan profesinya sebagai dosen dan bukan kepentingan organisasinya. Konflik peran terjadi jika individu mempunyai peran ganda yang bertentangan atau menerima berbagai pengharapan atas peran yang bertentangan atas jabatan tertentu.

Dari hasil analisis data dan pengujian hipotesis empat diatas diketahui bahwa variabel orientasi profesional merupakan variabel moderating karena interaksi konflik peran terhadap kinerja manajerial dengan orientasi profesional 
sebagai variabel pemoderasi, termasuk ke dalam jenis variabel moderasi kuadran 3 yaitu quasi moderator (moderator semu) dimana konflik peran berpengaruh secara langsung maupun berinteraksi dengan orientasi professional sebagai variabel pemoderasi terhadap kinerja manajerial Dengan demikian, orientasi profesional memperkuat hubungan antara konflik terhadap kinerja manajerial. Sehingga hasil penelitian ini menerima hipotesis empat.

Berdasarkan UU Nomor 14 tahun 2005 tentang Guru dan Dosen serta Peraturan Pemerintah Nomor 37 tahun 2009 tentang Dosen, secara jelas dinyatakan bahwa tugas utama seorang dosen adalah melaksanakan tridharma perguruan tinggi dengan beban kerja paling sedikit sepadan dengan 12 SKS dan paling banyak 16 SKS pada setiap semester sesuai dengan kualifikasi akademik yang dimilikinya. Sebagai seorang manager ada target yang akan dicapai dan mengukur sejauhmana tujuan organisasi dapat dicapai, misalnya jumlah lulusan yang dihasilkan sesuai dengan perencanaan, peningkatan akreditasi fakultas dan juga terlaksananya berbagai program dimasing-masing fakultas (peningkatan kualitas sember daya manusia, perbaikan pelayanan mahasiswa, dan lain-lain. Dengan sikap profesional sebagai dosen, seharusnya dapat meminimalkan konflik peran yang terjadi sehingga dua fungsi sebagai dosen dan sebagai manager dapat mencapai tujuan organisasi dengan baik dan tidak muncul perilaku yang bertentangan antara harapan manajemen dengan keinginan profesional.

Hasil hipotesis empat ini mendukung penelitian Puspa dan Riyanto (1999) yang menunjukkan bahwa kelompok profesional dosen, interaksi antara orientasi profesional dosen dan dominasi pengendalian output dapat meningkatkan konflik peranan yang selanjutnya menimbulkan penurunan kepuasan kerja. Namun konflik peran tersebut tidak mempengaruhi kinerja. Sedangkan untuk kelompok profesional dokter, tipe pengendalian yang tidak disukai adalah pengendalian prilaku, karena dapat meningkatkan konflik peran yang selanjutnya memberi pengaruh pada penurunan kinerja.

Luasnya konflik yang dialami para profesional tergantung seberapa tingginya mereka menjaga orientasi profesionalnya atau tergantung pada beralihnya orientasi ia menuju nilai dan norma organisasi. Semakin besar orientasi profesional 
yang dimiliki para manajer, semakin tinggi potensi konflik peran yang muncul. Orientasi para profesional yang tinggi tersebut kemungkinan menunjukkan keinginan untuk mencapai atau menjaga otonominya dalam lingkungan kerja. Pemikiran ini membawa konsekuensi bahwa individu yang menunjukkan orientasi profesional yang tinggi akan mengalami konflik karena mereka memandang nilai manajerial akan mengancam otonominya.

Perkembangan kegiatan penyelenggaran pendidikan tinggi di perguruan tinggi dan tuntutan yang mengharuskan dosen sebagai tenaga profesional untuk berintegrasi dalam manajerial perguruan tinggi, sebagai suatu upaya untuk mencapai efisiensi, efektivitas, transparansi dan akuntabilitas menyebabkan para profesional (dosen) memiliki peran ganda. Peran ganda sebagai profesional dan manajerial, yaitu sebagai dosen dan sebagai manajer di tingkat fakultas/unit kerja. Dimana masing masing peran memiliki ciri yang berbeda, yaitu nilai-nilai profesional dengan nilai-nilai manajerial.

Keterlibatan profesional dalam birokrat (manajemen) menjadi masalah tersendiri, karena keinginan profesional tidak hanya terlibat dalam pengendalian proses pekerjaan, tetapi juga pengendalian tujuan. Dimana tujuan implisit kebijakan manajemen birokrat adalah untuk mengendalikan perilaku profesional yang sering berseberangan dengan upaya efisiensi dan efektivitas dalam manajemen birokratik, yang sering menyentuh masalah krusial pada jasa profesional, yaitu penekanan pada efisiensi biaya.

Pada penelitian yang dilakukan oleh Yuniar (2010), memperlihatkan beberapa penelitian sebelumnya menunjukkan bahwa peran ganda yang dimiliki oleh profesional-manajerial berpotensi menimbulkan konflik. Penyebab timbulnya konflik tersebut karena adanya perbedaan antara nilai-nilai manajerial dengan nilainilai profesional. Nilai-nilai yang bertolak belakang tersebut harus diterapkan pada diri individu yang mempunyai peran ganda, berdasarkan penelitian tersebut, situasi itu dapat menimbulkan konflik pada diri individu tersebut. Konflik peran terjadi jika individu mempunyai peran ganda yang bertentangan atau menerima berbagai pengharapan atas peran yang bertentangan dari suatu jabatan tertentu. Konflik peran yang timbul pada para profesional yang ada dalam organisasi sektor 
pemerintahan, disebabkan oleh dua hal. Pertama, bahwa tugas-tugas birokrasi bersifat parsial sedangkan pekerjaan profesional bersifat keseluruhan. Kedua para birokrat loyal kepada organisasi dan meletigimasi tindakan mereka berdasarkan kompetensi yang dimiliki. Dalam penelitian ini, fokus konflik peran yang timbul disebabkan oleh adanya perbedaan tuntutan atas dua atau atau lebih peran yang harus dijalankan pada saat bersamaan (interrole conflict). Dimana, konflik peran yang dialami oleh dosen sebagai tenaga profesional yang menduduki jabatan struktural, ia mempunyai peran sebagai tenaga pengajar/dosen dan peran sebagai manajer. Dalam melaksanakan tugasnya, akan sering menerima dua perintah secara bersamaan. Pertama, perintah datangnya dari kode etik profesi dan kedua datangnya dari sistem pengendalian manajemen yang berlaku di organisasi. Apabila ia bertindak sesuai dengan kode etik, maka ia merasa tidak berperan sebagai pegawai yang baik. Sebaliknya, apabila ia bertindak sesuai dengan prosedur atau ketentuan yang telah ditentukan oleh organisasi, maka ia merasa telah bertindak secara tidak profesional benturan kedua mekanisme pengendalian ini terwujud dalam bentuk konflik peran (role conflict).

Menurut Aranya \& Ferris (1984) bahwa luasnya konflik yang dialami para profesional tergantung seberapa tingginya mereka menjaga orientasi profesionalnya menuju nilai dan norma organisasi. Semakin besar orientasi profesional yang dimiliki para manajer, semakin tinggi potensi konflik peran yang muncul. Kategori kelompok profesional diantaranya adalah ahli hukum, dokter, dan akademisi mencerminkan kelompok yang memiliki orientasi profesional yang tinggi (Yuniar, 2010).

Amilin \& Apriani (2013) menunjukkan bahwa orientasi profesional berpengaruh terhadap kinerja auditor. Semakin tinggi orientasi profesional, semakin tinggi kinerja yang dihasilkan auditor. Hal ini menunjukan bahwa apabila makin tinggi sikap keprofesionalan seseorang terkait dengan kode etik profesinya, maka kinerja yang dihasilkan pun makin baik. Hasil penelitian menyatakan bahwa konflik peran bukanlah variabel intervening. Hal ini dikarenakan standardized coefficient beta variable konflik peran memiliki nilai negatif. Berarti variabel konflik peran bukanlah variabel yang dapat memediasi variabel lainnya, yaitu variabel 
orientasi profesional (independen) dan kinerja auditor (dependen).

Suharmanto (2010) menjelaskan hasil penelitian yang dilakukan oleh Comerford dan Abernethy (1999) menyatakan bahwa apabila profesional perguruan tinggi dapat dibangkitkan untuk mengembangkan orientasi manajerial mereka, maka kemungkinan akan terdapat penurunan yang berkaitan dalam konflik peran. Lebih jauh, profesional tidak perlu mengorbankan orientasi profesional mereka untuk berpartisipasi secara efektif dalam jabatan formal mereka. Keterlibatan profesional perguruan tinggi dalam birokrasi, akan mengarahkan pada konflik peran apabila mereka tidak mempertahankan seperangkat nilai manajerial yang diperlukan, berupa orientasi manajerial dari organisasi dimana para profesional bekerja. Namun demikian temuan ini bukan tidak membawa tantangan yang signifikan bagi manajemen dari organisasi yang didominasi oleh para profesional, yaitu bagaimana menjaga keseimbangan dari ketiga variabel tersebut. Saran manajemen sumber daya manusia harus diimplementasikan untuk membangkitkan para profesional dalam mengambil orientasi manajerial, sementara mereka tetap mempertahankan komitmen profesional yang tinggi. Diharapkan dengan melibatkan profesional dalam peran-peran manajeral menyebabkan mereka dapat bersosialisasi dan memahami nilai-nilai organisasional. Implementasi program-program pengembangan manajemen yang meliputi pelatihan dalam teknik pengendalian dan pemecahan konflik juga dapat menjadi alat sosialisasi yang sangat kuat untuk membantu pengembangan orientasi tujuan sistem para profesional (Abernethy and Stoelwinder, 1991).

Hasil dari penelitian ini menyatakan orientasi professional yang tinggi tidak berpengaruh terhadap konflik peran, orientasi tujuan sistem tidak berpengaruh terhadap hubungan antara orientasi profesional dan konflik peran. Partisipasi penyusunan anggaran berpengaruh terhadap hubungan antara orientasi profesional dan konflik peran, sekaligus menunjukan bahwa hubungan antara orientasi profesional dan konflik peran dipengaruhi oleh variable moderating.

\section{SIMPULAN}

Berdasarkan hasil penelitian yang dilakukan untuk mengetahui pengaruh partisipasi anggaran dan konflik peran terhadap kinerja manajerial dan untuk 
mengetahui apakah keberadaan variabel moderating berupa orientasi profesional akan mempengaruhi interaksi antara partisipasi anggaran dan konflik peran terhadap kinerja manajerial, maka dapat ditarik kesimpulan sebagai berikut: Pertama, partisipasi anggaran tidak memiliki pengaruh yang signifikan terhadap kinerja manajerial. Hal ini dikarenakan dalam Perguruan Tinggi Negeri proses penyusunan anggaran secara partisipasif baru saja mulai dilakukan sehingga kurang maksimal dalam meningkatkan kinerja manajerial. Kedua, orientasi profesional merupakan variabel moderating karena interaksi partisipasi anggaran terhadap kinerja manajerial dengan orientasi profesional sebagai variabel pemoderasi. Orientasi profesional memperkuat hubungan antara partisipasi anggaran terhadap kinerja manajerial. Semakin tinggi orientasi profesional, semakin tinggi kinerja yang dihasilkan oleh manajerial. Hal ini menunjukan bahwa apabila makin tinggi sikap keprofesionalan seseorang terkait dengan kode etik profesinya, maka kinerja yang dihasilkan pun makin baik.

Ketiga, konflik peran memiliki pengaruh yang signifikan terhadap kinerja manajerial. Konflik peran dapat terjadi dikarenakan adanya dua fungsi yang berbeda dimana kedua fungsi tersebut mempunyai dua tujuan yang berbeda. Keempat, orientasi profesional merupakan variabel moderating karena interaksi konflik peran terhadap kinerja manajerial dengan orientasi profesional sebagai variabel pemoderasi. Orientasi para profesional yang tinggi tersebut kemungkinan menunjukkan keinginan untuk mencapai atau menjaga otonominya dalam lingkungan kerja. Pemikiran ini membawa konsekuensi bahwa individu yang menunjukkan orientasi profesional yang tinggi akan mengalami konflik karena mereka memandang nilai manajerial akan mengancam otonominya.

\section{PUSTAKA ACUAN}

Abernethy, M.A \& J.U. Stoelwinder. (1995). The Role of Professional Control in the Management of Complex Organization. Accounting, Organization and Society. Vol. 20 No.1: 1-16

Andison \& Y. Augustine. (2017). Partisipasi anggaran, kepuasan kerja dan kinerja manajerial: studi pada bisnis keluarga pempek di kota Palembang. Esensi: Jurnal Bisnis dan Manajemen. Volume 7 (1) Halaman 73 - 82. 
Amilin \& U. Apriani. (2013). Analisis Pengaruh Orientasi Profesional Terhadap Kinerja Auditor, Konflik Peran Sebagai Variabel Intervening. Jurnal Akuntabilitas. Vol. 6 (1): 21-30.

Lidya A. \& C.D.Karya Susilawati. (2009). Pengaruh Orientasi Profesional terhadap Konflik Peran: Partisipasi Anggaran dan Orientasi Tujuan Sistem sebagai Variabel Moderating (Studi pada Kantor Akuntan Publik di DKI Jakarta dan Bandung). Jurnal Akuntansi Vol.1 (2): 51-60.

Puspa., dan B. Riyanto., (1999). Tipe lingkungan Pengendalian Organisasi, Orientasi Professional, Konflik Peran, Kepuasan Kerja dan Kinerja: Suatu Penelitian Empiris". Jurnal Riset Akuntansi Indonesia, Vol. 2. (1): 117-135.

Suharmanto. (2010). Pengaruh orientasi profesional terhadap konflik peran: Interaksi antara penggunaan anggaran sebagai alat ukur kinerja dengan orientasi manajerial (Suatu Penelitian Empiris Pada Politeknik Negeri Semarang). Jurnal Administrasi Bisnis. Volume 11 (2): 115-124.

Supomo, B., \& N. Indriantoro. (1998). Pengaruh Struktur dan kultur Organisasi terhadap Keefektifan Anggaran Partiasipatif dalam Peningkatan Kinerja Manajerial. Kelola, No. 18/VIII: 61- 84.

Tjokorda, I.M.A., \& A.A.N.B. Dwirandra. (2013). Pengaruh Partisipasi Anggaran Terhadap Kinerja Manajerial Dengan Gaya Kepemimpinan dan Locus of Control Sebagai Variabel Moderasi. E-Jurnal Akuntansi Universitas Udayana. Vol. 4 (3): 311-320.

Yuniar, R. (2010). Pengaruh Orientasi Profesional Terhadap Konflik Peran dengan Variabel Moderating Partisipasi Anggaran dan Penggunaan Anggaran sebagai Alat Evaluasi Kerja. (Tesis Tidak Dipublikasikan). Bandung: Universitas Padjajaran. 